\title{
PENGARUH PENAMBAHAN TEPUNG JAHE DALAM PAKAN TERHADAP KADAR LEMAK DAN PROTEIN DAGING AYAM BROILER
}

\author{
Novia Syafitri ${ }^{1 *}$, Eti Meirina Brahmana ${ }^{1}$, Ria Karno $^{1}$ \\ ${ }^{1}$ Program Studi Pendidikan Biologi Fakultas Keguruan dan Ilmu Pendidikan \\ Universitas Pasir Pengaraian \\ Jl. Tuanku Tambusai Kumu Desa Rambah Kecamatan Rambah Hilir. Pasir Pengaraian \\ *Email: noviasyafitri27@gmail.com
}

\begin{abstract}
The purpose of this research was to know the influence of the addition of Ginger flour in the feed to the value of the levels of lipid and protein Broiler meat. These researches were conducted that used Soxhlet method to tested the lipid quality and Kjeldahl method to tested the protein. The sample were used Broiler aged 1 weeks up to 2 weeks, after 2 weeks old chicken was divided into 4 treatment groups of 6 each control group $\left(\mathrm{P}_{0}\right)$ without treatment, $\mathrm{P}_{1}$ with addition of ginger flour in feed $2.5 \%, \mathrm{P}_{2}$ in the addition of ginger flour in the diet of $5 \%, \mathrm{P}_{3}$ with the addition of ginger flour in the feed as much as $7.5 \%$. After 42 days old, Broiler conducted sampling of meat in the treatment for the examination of the levels of lipid and protein. The Data obtained are then analyzing used a One-way Anova. The result of these researches is in the range of lipid quality: $\mathrm{P}_{0}$ $(8,33 \%), \mathrm{P}_{1}(6,33 \%), \mathrm{P}_{2}(5,25 \%), \mathrm{P}_{3}(5,08 \%)$ After analyzed have done it shown there were differences that significance ( $p>0,05)$. Result of checked of protein quality: $\mathrm{P}_{0}(5,59 \%), \mathrm{P}_{1}(5,32 \%)$, $\mathrm{P}_{2}(5,36 \%), \mathrm{P}_{3}(5,45 \%)$ After analyzed were done there is no significance difference $(\mathrm{p}>0,05)$. The higher the percentage of ginger flour, the lower the fat content of broiler chicken.
\end{abstract}

Keywords: Broiler, Flour Ginger (Zingeber officinale Roscoe), The Levels of Lipid, Protein.

\section{PENDAHULUAN}

Daging ayam merupakan salah satu daging yang memegang peranan cukup penting dalam memenuhi kebutuhan gizi masyarakat. Dengan dagingnya yang lembut membuat masyarakat lebih banyak mengkonsumsinya dibanding ayam kampung. Selain itu harganya relatif murah sehingga masyarakat mampu membeli ayam Broiler. Daging ayam Broiler mempunyai konsentrasi kadar lemak yang sangat tinggi (Setyanto, Atmomarsono, \& Muryani, 2012). Ayam Broiler adalah ayam yang mempunyai sifat tenang, bentuk tubuh besar, pertumbuhan cepat, bulu merapat ke tubuh, kulit putih dan produksi telur rendah. Ayam Broiler merupakan salah satu ternak penghasil daging yang cukup untuk memenuhi kebutuhan masyarakat akan kebutuhan lemak dan protein hewani (Suprijatna, 2005). Konsumsi daging ayam Broiler ini meningkat paling pesat dibanding dengan daging sapi dan kambing. Cara menghasilkan ayam yang berkualitas tinggi dengan bantuan bahan alami tanpa obat kimia dapat dilakukan dengan berbagai cara, salah satunya menggunakan tepung jahe dalam pakan ayam Broiler (Zhang, G. F. et al., 2009). Penelitian yang telah dilakukan Sulistyoningsih (2014) menjelaskan bahwa jahe merah memiliki komponen zat aktif berupa minyak atsiri yang dapat menjadi antioksida dan diduga kuat dapat berpengaruh terhadap kadar lemak dalam tubuh. Minyak atsiri membantu kerja amilase, protease dan lipase sehingga laju pakan meningkat, 
Syafitri, N., Brahmana, EM., Karno,R. 2018. Pengaruh Penambahan Tepung Jahe dalam Pakan terhadap Kadar Lemak dan Protein Daging Ayam Broiler. Sainstek : Jurnal Sains dan Teknologi. 10 (1) : $1-4$

akhirnya produksi daging akan naik. Jahe berkhasiat menambah nafsu makan, memperkuat lambung dan memperbaiki pencernaan. Terangsangnya selaput lendir perut besar dan usus oleh minyak atsiri jahe, mengakibatkan lambung menjadi kosong dan ayam akan terdorong mengkonsumsi pakan.

Lemak merupakan salah satu zat gizi yang sangat diperlukan oleh tubuh, di samping zat gizi lain seperti karbohidrat, protein, vitamin dan mineral. Lemak merupakan salah satu sumber energi yang memberikan kalori paling tinggi (Sulistyoningsih, 2014). Jika di dalam tubuh kita terlalu banyak mengkonsumsi lemak maka akan mengakibatkan kegendutan atau obesitas, kolesterol tinggi, penyakit jantung dan mudah lelah (Batubara, 2009). Biasanya ayam diberi pur saja dengan bahan dasar yaitu jagung, kacang, umbi-umbian tepung tulang, kacang hijau. Kandungan yang terdapat pada pur 511 yaitu protein kasar 2123\%, lemak 5-8\%, serat kasar 3-5\%, abu 4-7\%. Sekarang diberikan pakan tambahan dengan menggunakan tepung jahe ke dalam pakan. Salah satu upaya untuk mengetahui pengaruh penambahan tepung jahe dalam pakan terhadap kadar lemak dan protein pada daging ayam Broiler sebagai alasan penelitian ini dilaksanakan.

\section{METODE PENELITIAN}

Penelitian ini menggunakan Rancangan Acak Lengkap (RAL) satu faktor dengan 4 perlakuan yaitu: $\mathrm{p}_{0}=$ menggunakan pur, $\mathrm{P}_{1}=$ $2,5 \%$ tepung jahe $\mathrm{P}_{2}=5 \%$ tepung jahe $\mathrm{p}_{3}=$ $7,5 \%$ tepung jahe. Percobaan dilakukan pada 4 kelompok sehingga terdapat 6 satuan percobaan. Penelitian ini menggunakan 24 ekor ayam pedaging yang dipelihara dari umur 7 hari hingga berumur 2 minggu, setelah berumur 2 minggu ayam dibagi dalam 4 kelompok perlakuan. Metode yang digunakan dalam penelitian ini adalah metode Soxhlet untuk Lemak dan metode Kjeldahl untuk Protein. Alat yang digunakan untuk penelitian adalah: Pisau, lampu pemanas bewarna kuning, Soxhlet Apparatus, Blender, Neraca Analitik, Pemanas Listrik, Labu Kjeldahl, Gelas Beker, Erlenmeyer, Destilasi dan Oven. Bahan yang digunakan untuk penelitian adalah: Daging ayam Broiler yang diberikan pakan tambahan Tepung Jahe, Plastik, Kertas Saring, $\mathrm{HCl}, \mathrm{N}-$ hexana, Aquades, Larutan Selen $\left(\mathrm{SeO}_{2}, \mathrm{~K}_{2} \mathrm{SO}_{4}\right.$ dan $\mathrm{CuSO}_{4} 5 \mathrm{H}_{2} \mathrm{O}$ ), Larutan Bromocresol Green, Larutan Merah Metil, Alkohol 95 \%, Indikator pp, Larutan Asam Borat. Asam Borat, Larutan $\mathrm{HCl} 0,01 \mathrm{~N}$ dan Larutan Natrium Hidroksida $30 \%$.

\section{HASIL DAN PEMBAHASAN}

Hasil pengamatan pengaruh penambahan tepung jahe (Zingiber officinale Roscoe) dalam pakan terhadap kadar lemak dan protein pada daging ayam broiler dapat dilihat pada Tabel 1.

Kadar lemak pada ayam Broiler kontrol $\left(\mathrm{P}_{0}\right)$ dengan nilai rata-rata $8,33 \%$ mengalami peningkatan dibandingkan dengan perlakuan $P_{1}$, $\mathrm{P}_{2}$, dan $\mathrm{P}_{3}$, karena pada kontrol atau $\mathrm{P}_{0}$ tidak diberikan penambahan tepung jahe ke dalam pakan. Dimana nilai persyaratan mutu kadar lemak ayam Broiler maksimal 8,0\% (Suci \& Hermana, 2012).

Tabel 1. Rata-rata Nilai Kadar Lemak Daging Ayam Broiler.

\begin{tabular}{cccc}
\hline Perlakuan & Ulangan & Kadar lemak \% & Kadar Lemak Gram \\
\hline $\mathrm{P}_{0}$ & 6 & $8,33 \%$ & 0,166 \\
$\mathrm{P}_{1}$ & 6 & $6,33 \%$ & 0,126 \\
$\mathrm{P}_{2}$ & 6 & $5,25 \%$ & 0,105 \\
$\mathrm{P}_{3}$ & 6 & $5,08 \%$ & 0,101 \\
\hline
\end{tabular}


Syafitri, N., Brahmana, EM., Karno,R. 2018. Pengaruh Penambahan Tepung Jahe dalam Pakan terhadap Kadar Lemak dan Protein Daging Ayam Broiler. Sainstek : Jurnal Sains dan Teknologi. 10 (1) : $1-4$

Kadar lemak pada ayam Broiler perlakuan $\left(\mathrm{P}_{1}\right)$ dengan penambahan tepung jahe $2,5 \%$ dalam pakan memiliki nilai rata-rata 6,33\% mengalami penurunan, dibandingkan dengan $\mathrm{P}_{0}$ dan nilai kadar lemak $\mathrm{P}_{1}$ tidak berbeda nyata dengan $\mathrm{P}_{2}$, dan $\mathrm{P}_{3}$. Kadar lemak pada ayam Broiler perlakuan $\left(\mathrm{P}_{2}\right)$ dengan penambahan tepung jahe $5 \%$ dalam pakan memiliki nilai rata-rata $5,25 \%$ mengalami penurunan, dibandingkan dengan $\mathrm{P}_{0}$ dan nilai kadar lemak $\mathrm{P}_{2}$ tidak berbeda nyata dengan $\mathrm{P}_{1}$, dan $\mathrm{P}_{3}$. Kadar lemak pada ayam Broiler perlakuan $\left(\mathrm{P}_{3}\right)$ dengan penambahan tepung jahe $7,5 \%$ dalam pakan memiliki nilai rata-rata $5,08 \%$ mengalami penurunan, dibandingkan dengan $\mathrm{P}_{0}$ dan nilai kadar lemak $\mathrm{P}_{3}$ tidak berbeda nyata dengan $\mathrm{P}_{1}$, dan $\mathrm{P}_{2}$.

Hasil penelitian diuji dengan statistik menggunakan analisis ragam menunjukkan ada perbedaan yang signifikan atau nilai $\mathrm{P}(0,001)$ lebih kecil dari batas kritis 0,05 maka $H_{1}$ diterima dan $H_{0}$ ditolak. Dilanjutkan dengan uji beda nyata terkecil (BNT) menunjukkan penggunaan presentasi yang paling efektif adalah P1 dengan penambahan tepung jahe 2,5\%. Rata-rata kadar lemak secara berturutturut kontrol dan perlakuan adalah 8,33, 6,33, 5,25 , dan 5,08, dan rata-rata kadar lemak jika dalam gram (gr) adalah 0,166 gram, 0,126 gram, 0,105 gram, 0,101 gram.

Kadar protein pada ayam broiler kontrol $\left(\mathrm{P}_{0}\right)$ dengan nilai rata-rata $5,59 \%$ tidak mengalami penurunan dan peningkatan dibandingkan dengan perlakuan $\mathrm{P}_{1}, \mathrm{P}_{2}$, dan $\mathrm{P}_{3}$ (lihat Tabel 2). Hal ini disebabkan karena pada uji Anova tidak terdapat perbedaan yang signifikan yang berarti tidak mengalami penurunan dan peningkatan pada setiap perlakuan, meskipun pada kontrol dan perlakuan mengalami peningkatan atau pun penurunan. Dimana nilai persyaratan mutu kadar lemak ayam Broiler maksimal 18,0\% (Suci \& Hermana, 2012).

Kadar protein pada ayam Broiler perlakuan $\left(\mathrm{P}_{1}\right)$ dengan penambahan tepung jahe $2,5 \%$ dalam pakan memiliki nilai rata-rata $5,32 \%$ tidak mengalami penurunan dan peningkatan dibandingkan dengan $\mathrm{P}_{0}, \mathrm{P}_{2}$, dan $\mathrm{P}_{3}$. Kadar protein pada ayam Broiler perlakuan $\left(\mathrm{P}_{2}\right)$ dengan penambahan tepung jahe $5 \%$ dalam pakan memiliki nilai rata-rata 5,36\% tidak mengalami penurunan dan peningkatan dibandingkan dengan $\mathrm{P}_{0}, \mathrm{P}_{1}$, dan $\mathrm{P}_{3}$. Kadar protein pada ayam Broiler perlakuan $\left(\mathrm{P}_{3}\right)$ dengan penambahan tepung jahe $7,5 \%$ dalam pakan memiliki nilai rata-rata $5,45 \%$ tidak mengalami penurunan dan peningkatan dibandingkan dengan $\mathrm{P}_{0}, \mathrm{P}_{1}$, dan $\mathrm{P}_{2}$.

Hasil penelitian diuji dengan statistik menggunakan analisis ragam menunjukkan tidak terdapat perbedaan yang signifikan atau nilai $\mathrm{P}(0,288)$ lebih besar dari batas kritis 0,05 maka $H_{0}$ diterima dan $H_{1}$ ditolak. Rata-rata kadar protein secara berturut-turut kontrol dan perlakuan dalam persen $(\%)$ adalah $5,59 \%$, $5,32 \%, 5,36 \%$, dan $5,45 \%$, dan rata-rata kadar protein jika dalam gram (gr) adalah 0.0559 gram, 0,0532 gram, 0,0536 gram, 0,0545 gram.

Tabel 2. Rata-Rata Nilai Kadar Protein Daging Ayam Broiler.

\begin{tabular}{cccc}
\hline Perlakuan & Ulangan & Kadar Protein \% & Kadar Protein Gram \\
\hline $\mathrm{P}_{0}$ & 6 & $5,59 \%$ & 0,0559 \\
$\mathrm{P}_{1}$ & 6 & $5,32 \%$ & 0,0532 \\
$\mathrm{P}_{2}$ & 6 & $5,36 \%$ & 0,0536 \\
$\mathrm{P}_{3}$ & 6 & $5,45 \%$ & 0,0545 \\
\hline
\end{tabular}




\section{KESIMPULAN}

Dari hasil penelitian dan pembahasan yang telah dilakukan maka dapat diambil kesimpulan sebagai berikut :

Kadar lemak pada ayam Broiler kontrol $\left(\mathrm{P}_{0}\right)$ dengan nilai rata-rata $8,33 \%$ mengalami peningkatan dibandingkan dengan perlakuan $P_{1}$, $\mathrm{P}_{2}$, dan $\mathrm{P}_{3}$, karena pada kontrol atau $\mathrm{P}_{0}$ tidak diberikan penambahan tepung jahe ke dalam pakan. Dimana nilai persyaratan mutu kadar lemak ayam Broiler maksimal $8,0 \%$. Penambahan tepung jahe pada pakan berpengaruh nyata terhadap nilai kadar lemak pada daging ayam Broiler $(\mathrm{p} \leq 0,05)$ rata-rata kadar lemak 8,33, 6,33, 5,25, dan 5,08 dan rata-rata kadar lemak jika dalam gram (gr) adalah 0,166 gram, 0,126 gram, 0,105 gram, 0,101 gram.

Kadar protein pada ayam broiler kontrol $\left(\mathrm{P}_{0}\right)$ dengan nilai rata-rata $5,59 \%$ tidak mengalami penurunan dan peningkatan dibandingkan dengan perlakuan $\mathrm{P}_{1}, \mathrm{P}_{2}$, dan $\mathrm{P}_{3}$. Hal ini disebabkan karena pada uji Anova tidak terdapat perbedaan yang signifikan yang berarti tidak mengalami penurunan dan peningkatan pada setiap perlakuan, meskipun pada kontrol dan perlakuan mengalami peningkatan atau pun penurunan. Dimana nilai persyaratan mutu kadar lemak ayam Broiler maksimal 18,0\%. Penambahan tepung jahe pada pakan tidak berpengaruh nyata terhadap nilai kadar protein pada daging ayam Broiler $(\mathrm{p} \geq 0,05)$ dalam persen $(\%)$ adalah $5,59 \%, 5,32 \%, 5,36 \%$, dan $5,45 \%$, dan rata-rata kadar protein jika dalam gram (gr) adalah 0.0559 gram, 0,0532 gram, 0,0536 gram, 0,0545 gram.

\section{DAFTAR KEPUSTAKAAN}

Batubara, U. N. (2009). Analisa protein kalsium dan lemak pada ikan Porapora. Skripsi Universitas Sumatera Utara Medan.

Setyanto, A., Atmomarsono, U., \& Muryani, R. (2012). Pengaruh Penggunaan Tepung Jahe Emprit (Zingiber officinale var Amarum) dalam Ransum terhadap Laju Pakan dan Kecernaan Pakan Ayam Kampung Umur 12 Minggu. Animal Agriculture Journal, 1 (1), 716 - 717.

Suci, D. M., \& Hermana, W. (2012). Pakan Ayam. Penebar Swadaya: Jakarta.

Sulistyoningsih, M. (2014). Optimalisasi produksi broiler melalui suplementasi herbal terhadap persentase karkas dan kadar trigliserida darah. Prosidding: Universitas FPMIPA IKIP PGRI Semarang, 3 (1), 85-92.

Suprijatna, A. (2005). Ayam-Ayam Pedaging Unggul. Penerbit $C V$. Aneka: Solo.

Zhang, G. F., Z. B., Yang., Y., Wang., W. R., Yang., S. Z., Jiang, \& Gai., G. S. (2009). Effects of ginger root (Zingiber officinale) processed to different particle sizes ongrowth performance, antioxidant status, and serum metabolites of broilerchickens. Poultry Science, 88, 2159-2160. 